\title{
Allium cepa L. Inoculation with a Consortium of Plant Growth-Promoting Bacteria: Effects on Plants, Soil, and the Autochthonous Microbial Community
}

\author{
Marika Pellegrini ${ }^{1,2, *(\mathbb{D}}$, Daniela M. Spera ${ }^{1}\left(\mathbb{D}\right.$, Claudia Ercole $^{2}$ and Maddalena Del Gallo ${ }^{2}$ (D) \\ 1 AGIRE Soc. Cons. a r.l., Via Isidoro e Lepido Facii, 64100 Teramo, Italy; danielamspera@gmail.com \\ 2 Department of Life, Health and Environmental Sciences, University of L'Aquila, Via Vetoio, Coppito, \\ 67010 L'Aquila, Italy; claudia.ercole@univaq.it (C.E.); maddalena.delgallo@univaq.it (M.D.G.) \\ * Correspondence: marika.pellegrini@univaq.it; Tel.: +39-0862-433258
}

Citation: Pellegrini, M.; Spera, D.M.; Ercole, C.; Del Gallo, M. Allium cepa L. Inoculation with a Consortium of Plant Growth-Promoting Bacteria: Effects on Plants, Soil, and the Autochthonous Microbial Community. Microorganisms 2021, 9 , 639. https://doi.org/10.3390/ microorganisms 9030639

Academic Editor: Elisa Gamalero

Received: 28 February 2021

Accepted: 16 March 2021

Published: 19 March 2021

Publisher's Note: MDPI stays neutral with regard to jurisdictional claims in published maps and institutional affiliations.

Copyright: (c) 2021 by the authors. Licensee MDPI, Basel, Switzerland. This article is an open access article distributed under the terms and conditions of the Creative Commons Attribution (CC BY) license (https:// creativecommons.org/licenses/by/ $4.0 /)$.

\begin{abstract}
The present work was aimed at investigating the effects of a four bacterial strain consortiumAzospirillum brasilense, Gluconacetobacter diazotrophicus, Herbaspirillum seropedicae, and Burkholderia ambifaria - on Allium cepa L. and on soil health. The bacterial consortium was inoculated on seeds of two different onion varieties; inoculated and Control seeds (treated with autoclaved inoculum) were sown in an open-field and followed until harvest. Plant growth development parameters, as well as soil physico-chemical and molecular profiles (DNA extraction and $16 \mathrm{~S}$ community sequencing on the Mi-Seq Illumina platform), were investigated. The results showed a positive influence of bacterial application on plant growth, with increased plant height $(+18 \%)$, total chlorophylls $(+42 \%)$, crop yields $(+13 \%)$, and bulb dry matter $(+3 \%)$ with respect to the Control. The differences between Control and treatments were also underlined in the bulb extracts in terms of total phenolic contents $(+25 \%)$ and antioxidant activities $(+20 \%)$. Soil fertility and microbial community structure and diversity were also positively affected by the bacterial inoculum. At harvest, the soil with the presence of the bacterial consortium showed an increase in total organic carbon, organic matter, and available phosphorus, as well as higher concentrations of nutrients than the Control. The ecological indexes calculated from the molecular profiles showed that community diversity was positively affected by the bacterial treatment. The present work showed the effective use of plant growth-promoting bacteria as a valid fertilization strategy to improve yield in productive landscapes whilst safeguarding soil biodiversity.
\end{abstract}

Keywords: biostimulants; PGPB; seed inoculation; sustainable agriculture; illumina sequencing

\section{Introduction}

One of the current concerns in agriculture is to improve the sustainability of productive land and at the same time to achieve high production rates. To achieve this goal, one of the promising and sustainable innovations could be the use of natural plant biostimulants [1]. Plant biostimulants are substances or microorganisms applied to plants for the enhancement of nutrition, tolerance to abiotic stress, and improvement in crop quality traits [2]. Plant biostimulants can be classified into nine categories based on their non-microbial and microbial natures and origin [3]. Among them, plant growth-promoting bacteria (PGPB) are considered sustainable biostimulant agents, effective also in the presence of abiotic stress factors [1]. Several strains are associated with the PGPB group based on their plant growth-promoting (PGP) traits. Among them, key traits are nitrogen fixation, nutrient-solubilising capabilities, and the production of phytohormones [4,5]. PGPB can be applied on seeds or to soil through several formulation (e.g., encapsulated, inorganic, liquid, organic, polymeric), which can influence the biostimulant effectiveness [6]. However, seed inoculation is the most common method of application [6]. In this work, we investigated the biostimulating efficacy of seed inoculation with a bacterial consortium consisting of Azospirillum brasilense Cd, Burkholderia ambifaria PHP7, Gluconacetobacter diazotrophicus 
Pal5, and Herbaspirillum seropedicae Z67. A. brasilense belongs to one of the most studied PGPB genera [7] with good biofertilisation potential [8-14]. The mechanisms of action by which Azospirillum spp. improve plant growth involve the production of phytohormones, $\mathrm{N}_{2}$-fixation, the mobilization of minerals, the production of small molecules and enzymes, the proliferation of the root system, the improvement of membrane activity, and the uptake of water and minerals [7]. To Gluconacetobacter spp. are attributed $\mathrm{N}_{2}$-fixation, the production of siderophores and phytohormones, and the solubilization of inorganic forms of phosphorus and zinc [15]. In addition to phytohormones and siderophore production and $\mathrm{N}_{2}$-fixation, Herbaspirillum spp. and PGP Burkholderia species help plants to thrive thanks to the presence of 1-aminocyclopropane-1-carboxylate (ACC) deaminase, which reduces stressful ethylene levels [16-18]. In addition, direct and indirect biocontrol capabilities of bacterial and fungal phytopathogens have been reported for all these strains $[7,15,16,18]$. The production of bacterial consortia, with the combination of two or more strains with PGP characteristics, can increase the effectiveness of the inoculum $[19,20]$. The combination of A. brasilense, B. ambifaria, G. diazotrophicus, and H. seropedicae strains has already shown good biostimulation effects on Lycopersicon esculentum L. [21] Cannabis sativa L. [22] Artemisia eriantha Ten [23], and ancient Triticum genotypes [24]. In the present work, we hypothesised that this PGPB consortium could positively affect the growth, development, yield, and quality traits of Allium cepa L. crops. To demonstrate the validity of this hypothesis, two onion cultivars suitable for the experimental area were chosen, "Meranto" and "Moondance". First, bacterial association on inoculated seeds and colonization of seedlings grown in vitro were evaluated by Scanning Electron Microscope (SEM). Then, two parallel one-year field experiments were carried out to evaluate the efficacy of the PGPB treatment on plants (i.e., chlorophyll, length, dry weight) and bulbs (i.e., dry weight, total phenolic content, antioxidant activity) of both onion varieties. To evaluate the influence of this treatment on soil microbial communities, soil samples were also analyzed in terms of physico-chemical and molecular profiles.

\section{Materials and Methods}

\subsection{Bacterial Strains and Growth Conditions}

Meranto (Bejo Italia Srl, Ravenna, Italy) and Moondance F1 (Vilmorin, Paris, France) onion cultivars were utilized in the present study. Bacteria were grown in T4 medium [21] with constant shaking at $30{ }^{\circ} \mathrm{C}$ for $24 \mathrm{~h}$. The cell density of each strain was determined spectrophotometrically, by comparing optical densities at $600 \mathrm{~nm}$ with calibration curves. The four strains were mixed to obtain an equal number of cells for each strain and a working inoculum with a final density of $10^{10}$ cells $\mathrm{mL}^{-1}$. Seeds were treated with the inoculum by immersion for $20 \mathrm{~min}$. Then, the seeds were removed from the inoculum and dried overnight at $30^{\circ} \mathrm{C}$. The final bacterial density on seeds was $10^{6}$ cells $\mathrm{g}^{-1}$ (determined by a plate count on T4). The Control consisted of seeds inoculated with the same procedure, but with autoclaved inoculum.

\subsection{Bacterial Adhesion on Seed Surfaces Investigated by Scanning Electron Microscopy}

Seeds were sterilized following the procedure previously described [24]. Sterilized seeds were inoculated with the $10^{10} \mathrm{~mL}^{-1}$ bacterial suspension for $20 \mathrm{~min}$ and allowed us to dry overnight at $30^{\circ} \mathrm{C}$. Control seeds were treated with the same procedures but with a bacterial suspension autoclaved for $15 \mathrm{~min}$ at $120^{\circ} \mathrm{C}$. Surfaces and sections (obtained with a sterile lancet) of Control and inoculated seeds were analyzed the day of inoculation and 30 days later. Samples were directly positioned on metal sample holders by double-sided adhesive carbon tape in thermal contact with a Peltier cooling stage maintained at $-1{ }^{\circ} \mathrm{C}$. Samples were then analyzed by a Gemini500 scanning electron microscope (SEM-Zeiss, Oberkochen, Germany) operating in wet mode conditions (working distance 6.5-8 mm, variable pressure, accelerating voltage $10 \mathrm{kV}$, relative humidity $80 \%$, back-scatter electron detector). 


\subsection{Experimental Design and Experimental Conditions}

Two parallel field experiments were carried out during the growing season, FebruaryAugust 2019, at the Agricola Scipioni fields (Avezzano, Italy, $650 \mathrm{~m}$ above sea level), characterised by a relatively continental climate, with an average annual rainfall range of 650-800 mm. The onion seeds were sown in February 2019 with a pneumatic seeder (Serie SNT, Agricola Italiana SNC, Massanzago, PD, Italy), 250 seeds $\mathrm{m}^{2}$, with five rows of tandem plants spaced $5 \mathrm{~cm}$ apart. The previous crop was potato (Solanum tuberosum L.), harvested in mid-October 2018. The fields were previously fallow, plowed, and harrowed twice before sowing. Two experimental conditions were compared: seeds treated with the bacterial consortium (PGPB) and seeds treated with the autoclaved consortium (Control). The experimental design consisted of a split plot design with five replications, where onion cultivars (Meranto and Moondance) represented the main plots and seed treatment (PGPB and Control) the sub-plots. Each experimental unit covered an area of $5.0 \mathrm{~m} \times 6.0 \mathrm{~m}$ $\left(30 \mathrm{~m}^{2}\right)$.

\subsection{Crop Monitoring and Sampling}

From 15 days after sowing (DAS) up to 150 DAS, plant height was monitored and aerial part samples were collected randomly within each experimental unit. The aerial parts were taken to the laboratory and analyzed for dry weight $\left(80^{\circ} \mathrm{C}\right.$ to constant weight) and chlorophyll content [25]. At harvest (180 DAS), bulbs were collected and yields ( $\mathrm{t} \mathrm{ha}^{-1}$ ) estimated. Bulb samples were randomly collected within each experimental unit, taken to the laboratory, and processed for further investigations as described in Section 2.5.

\subsection{Bulb Analyses}

Bulbs were investigated for their dry weight, total phenolic contents, and antioxidant activity. Dry weight was obtained by heat treatment of bulb slices at $80{ }^{\circ} \mathrm{C}$ to constant weight. For total phenolic content and antioxidant activity, bulb slices were immediately frozen at $-80^{\circ} \mathrm{C}$ and freeze-dried completely (15 h). Lyophilized samples were then hermetically packed in high-barrier plastic bags and kept at $-80{ }^{\circ} \mathrm{C}$ until analysis. Five replicates per each sample were extracted by $1 \mathrm{~min}$ microwave extraction $(350 \mathrm{~W})$ with a 50:50 (v/v) ethanol-water solution and a sample-solution ratio of 1:25. The total phenolic content assay was carried out utilizing Folin-Ciocâlteu reagent and the Singleton and Rossi procedure [26]. Gallic acid was used as a reference standard, and results were expressed as mg GAE (gallic acid equivalents) $\mathrm{g}^{-1} \mathrm{DW}$ (dry weight). Antioxidant activity was estimated using the DPPH (2,2'-diphenyl-1-picrylhydrazyl) radical, following the procedure described by Brand-Williams et al. [27]. Results were expressed as $\mathrm{IC}_{50}(\mathrm{mg}$ $\mathrm{mL}^{-1}$ extract concentration able to inhibit $50 \%$ of DPPH). All standard and reagents were purchased from Merc (Darmstadt, Germany).

\subsection{Soil Analyses}

Before sowing and at harvest (development stage 49), five soil samples for each experimental unit were randomly collected at $0-10 \mathrm{~cm}$ depth. The five samples were thoroughly mixed to obtain a global soil sample, which was sieved $(<2 \mathrm{~mm})$ to remove plant roots, fauna, and debris before analysis. Soil chemical analyses were carried out according to the methods described in "DM 13/09/1999 GU N'248 21/10/1999". Genomic DNA was extracted from three global soil sample replications utilizing the NucleoSpin ${ }^{\circledR}$ Soil kit (Macherey Nagel, Germany), following the manufacturer's protocol. DNA quantification of the samples was performed using the Qubit dsDNA HS (High Sensitivity) Assay Kit and a Qubit Fluorometer (ThermoFisher Scientific, Waltham, MA, USA). Replications of each sample were pooled in equimolar mixtures, and samples were sent for $16 \mathrm{~S}$ rRNA sequencing to Bio-Fab Research Srl (Rome, Italy) as previously described [28]. 


\subsection{Data Handling and Statistical Analysis}

With respect to the results of the field experiments, a $t$-test was applied to test the differences $(\alpha=0.001)$ between Control and treated samples by cultivar (XLSTAT 2016Addinsoft, Paris, France).

16S rRNA sequencing classifications were obtained utilizing the SILVA 132 database (https:/ / www.arb-silva.de/, accessed on 27 February 2021) and the amplicon sequence variants (ASVs) method. Results were processed by QIIME2 [29], and diversity indices were calculated using the R (R Foundation for Statistical Computing, Vienna, Austria) statistical package vegan v. 2.5-7 [30].

\section{Results}

To evaluate the bacterial adhesion on seed surfaces, SEM observations of Control and inoculated seeds were carried out. Control seeds showed clear surfaces, while high bacterial adhesion was observed under the PGPB condition (Figure 1A). The bacteria were able to adhere to the seed surfaces and establish aggregation structures that allowed them to persist for up to 30 days (Figure 1B). We also tested inoculum persistence on seeds kept in the dark at room temperature. After 30 days, the number of bacteria present on the seeds remained unchanged. After 60 days, the number of bacteria decreased by $0.5 \log \mathrm{CFU} \mathrm{g}{ }^{-1}$.

During growth, heights, dry weight, and chlorophylls of the aerial parts were monitored. Figure 2 shows the recorded height dynamics for Meranto and Moondance crops from 15 to $150 \mathrm{DAS}$. The height of the aerial part was significantly affected $(p<0.05)$ by the bacterial treatment. Throughout the entire growth period, the PGPB condition recorded higher values than the Control, reaching a final average increase of $18 \%$ at 150 DAS. Similar trends were also shown by dry weight dynamics (Figure 3); the PGPB condition recorded a final average increase of $23 \%$ over the Control. The improvement induced by the bacterial treatment of the seeds was also emphasized by the chlorophyll content. As shown in Figure 4, the treated plants (PGPB) recorded significant increases in chlorophyll content compared to the Control until late maturation (150 DAS), at which an average increase of $43 \%$ was recorded.

At harvest, the total yields $\left(\mathrm{t} \mathrm{ha}^{-1}\right)$ were estimated. For the Moondance cultivar, the PGPB condition recorded an average increase of $14 \%$, while for Meranto, the average was $12 \%$. These increases were related to the greater biomass developed by the bulbs in response to bacterial inoculation, which is also easily understandable from Figure 5.

For both Meranto and Moondance varieties, greater dry weights of bulbs were recorded $(p<0.001)$, with an average increase of $3 \%$ (Table 1$)$.

Table 1. Dry weight, total phenolic content, and antioxidant activity of bulbs of Meranto and Moondance cultivars.

\begin{tabular}{|c|c|c|c|c|}
\hline \multicolumn{2}{|c|}{ Index } & \multirow{2}{*}{$\begin{array}{c}\text { Dry Weight } \\
\text { (\%) }\end{array}$} & \multirow{2}{*}{$\begin{array}{c}\text { Total Phenolic Content } \\
\text { (mg GAE g-1 DW) }\end{array}$} & \multirow{2}{*}{$\begin{array}{c}\begin{array}{c}\text { Antioxidant Activity } \\
\text { (IC50) }\end{array} \\
150.92\end{array}$} \\
\hline & Control & & & \\
\hline Moondance & PGPB & 14.73 & 5.96 & 12.71 \\
\hline \multirow{4}{*}{ Meranto } & $t$-test & * & $* * *$ & $* *$ \\
\hline & Control & 14.21 & 3.97 & 93.32 \\
\hline & PGPB & 14.70 & 4.97 & 75.10 \\
\hline & $t$-test & $*$ & $* * *$ & * \\
\hline
\end{tabular}

$t$-test: ${ }^{*}=p<0.001{ }^{* *}=p<0.01 ;{ }^{* * *}=p<0.05$.

The bulbs were also analyzed for total phenolic contents and antioxidant activity (Table 1). The bacterial treatment was able to induce an increase in phenols in both Meranto and Moondance bulbs $(p<0.05)$, stimulating the production and accumulation of secondary metabolites. The presence of a larger amount of phenols and possibly other bioactive molecules also induced an increase in antioxidant activity $(p<0.01)$.

To evaluate the inoculum effects on soil fertility status, pre-sowing and post-harvest soil samples were subjected to physico-chemical characterization and DNA extraction and 
$16 \mathrm{~S}$ rRNA analysis. Soil physico-chemical changes recorded for Meranto and Moondance experimental conditions were similar (Table 2). Regarding the pre-sowing soil, PGPB samples recorded increases in total organic $\mathrm{C}$ and organic matter. Conversely, the Controls recorded decreases in the same parameters. The presence of the inoculum also induced a decrease in $\mathrm{Na}^{+}$and electrical conductivity and a change in the composition of soil nutrients. Compared to the soil collected at pre-sowing, the contents of $\mathrm{Ca}^{++}, \mathrm{Mg}^{++}$, and $\mathrm{K}^{+}$decreased in the Control samples but not in those inoculated with PGPB, while for the available phosphorus, there was an increase in the PGPB samples and a decrease in those of the Control.
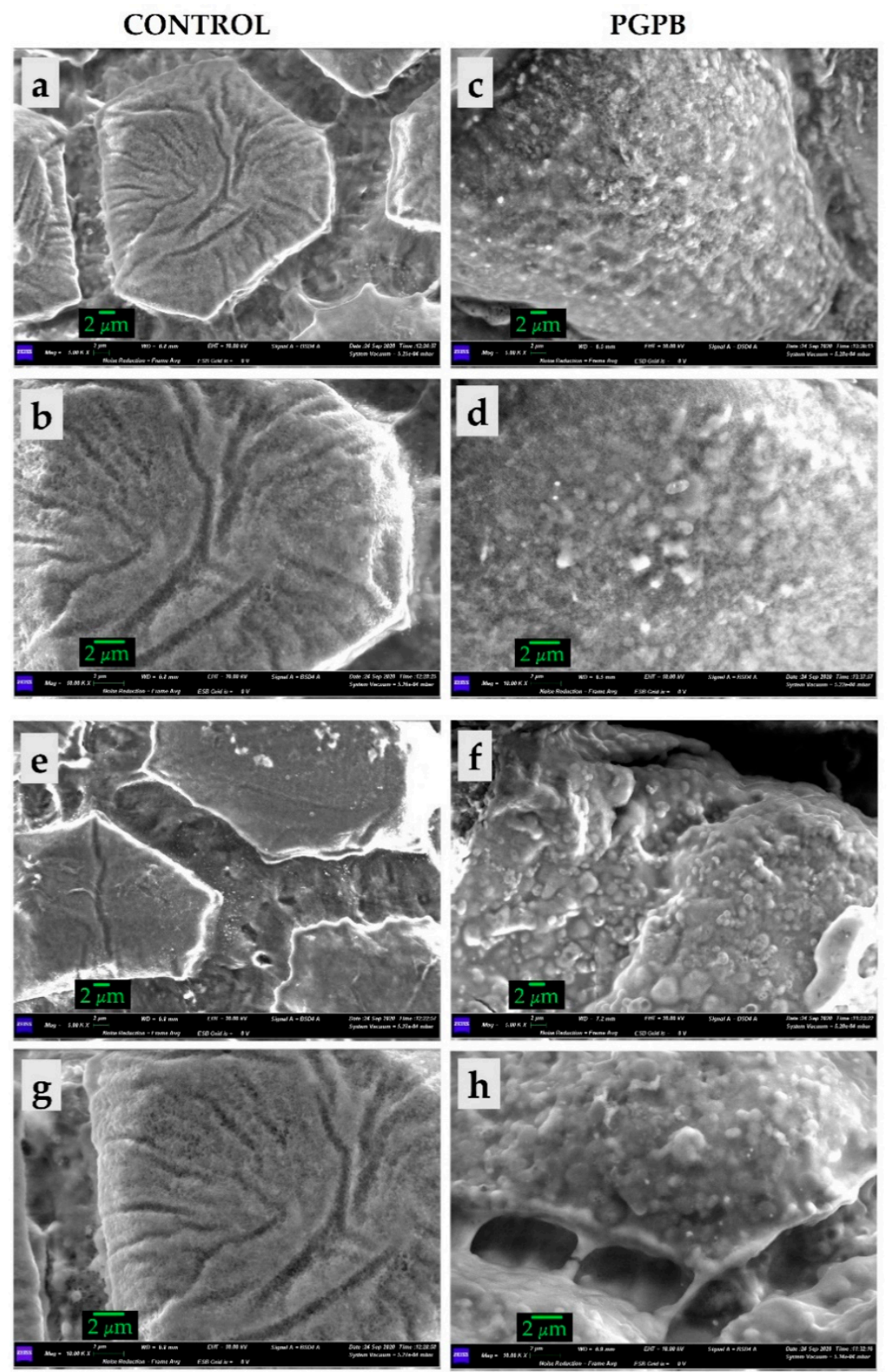

Figure 1. Scanning electron microscope (SEM) micrographs obtained for (a) Control (CNT) and inoculated (PGPB) Allium cepa seeds the same day of the inoculation (a-d) and after 30 days (e-g). Magnitudes: $5000 \times(\mathbf{a}, \mathbf{c}, \mathbf{e}, \mathbf{g})$ and 10,000 $\times(\mathbf{b}, \mathbf{d}, \mathbf{f}, \mathbf{h})$. Scale bars $2 \mu \mathrm{m}$. 


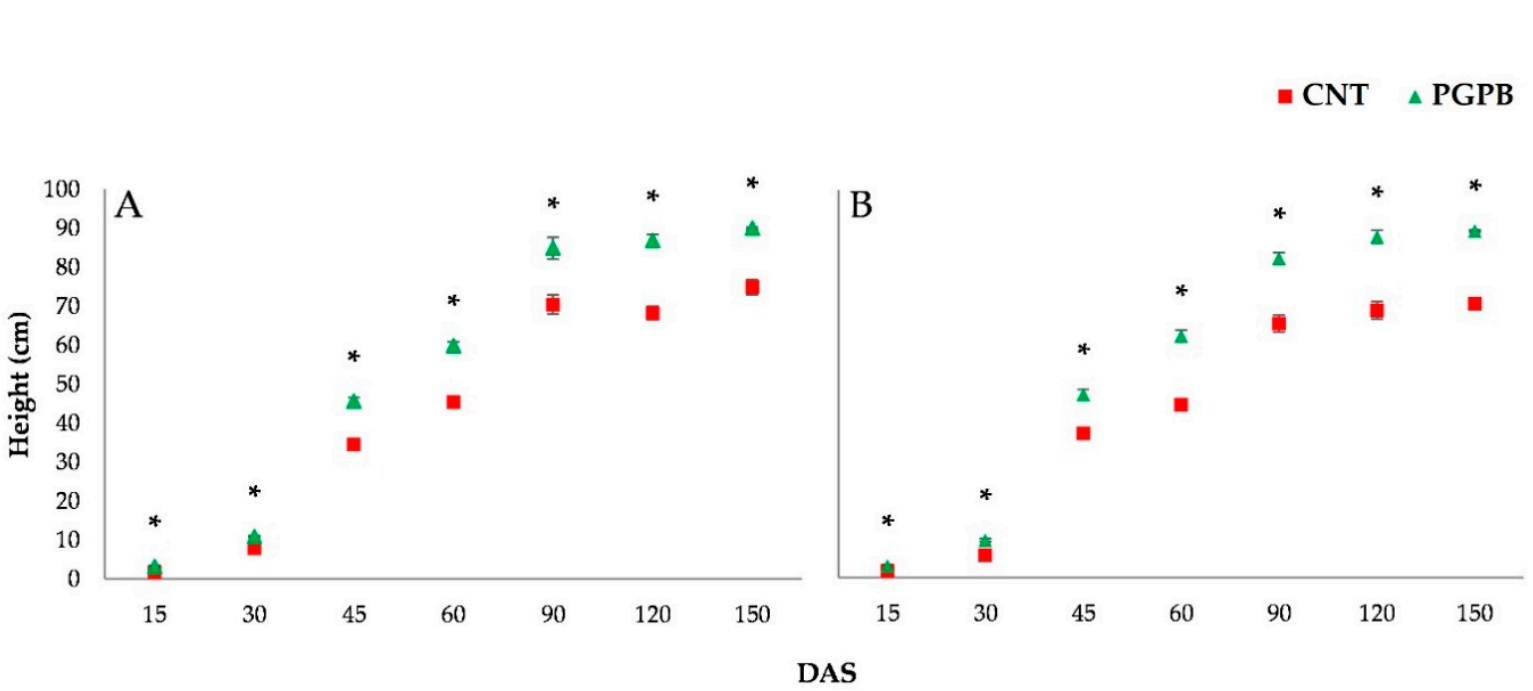

Figure 2. Height dynamics recorded for Meranto (A) and Moondance (B). In the figure: CNT $=$ Control; PGPB = treated seed; DAS = days after sowing; ${ }^{*}=p<0.001$.

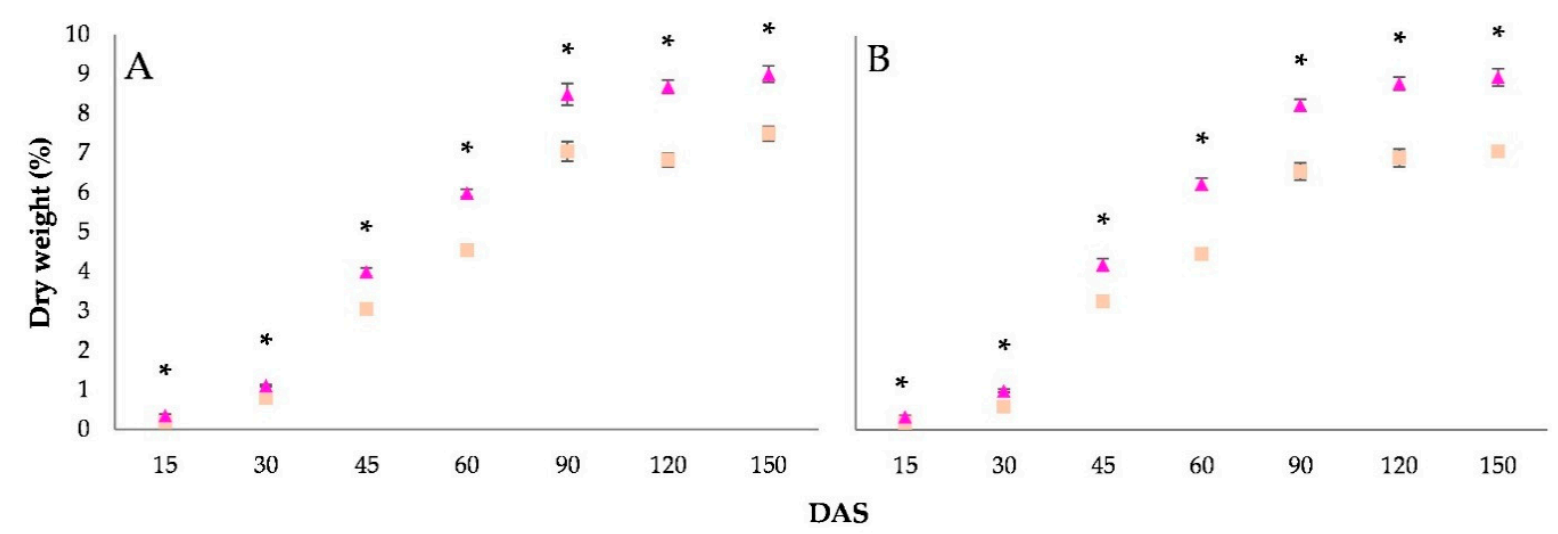

Figure 3. Dry weight dynamics recorded for Meranto $(\mathbf{A})$ and Moondance $(\mathbf{B})$. In the figure: $\mathrm{CNT}=\mathrm{Control} ; \mathrm{PGPB}=$ treated seed; DAS = days after sowing; ${ }^{*}=p<0.001$.

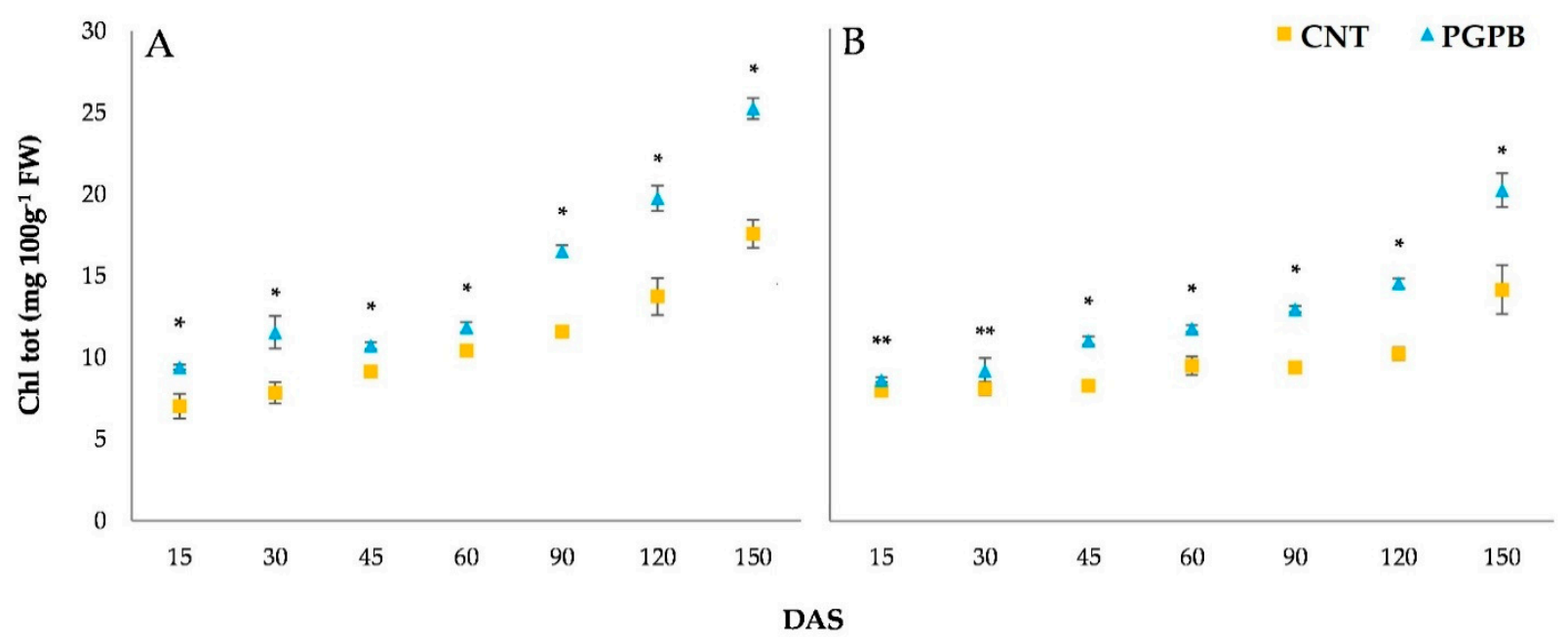

Figure 4. Dynamics of the total chlorophyll content $\left(\mathrm{mg} 100 \mathrm{~g}^{-1} \mathrm{FW}\right)$ recorded for Meranto (A) and Moondance (B). In the figure: $\mathrm{CNT}=$ Control; $\mathrm{PGPB}=$ treated seed; DAS = days after sowing; ${ }^{*}=p<0.001 ;{ }^{* *}=p<0.01$. 


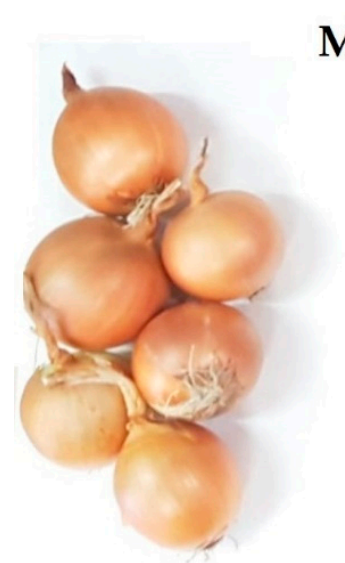

PGPB
Meranto

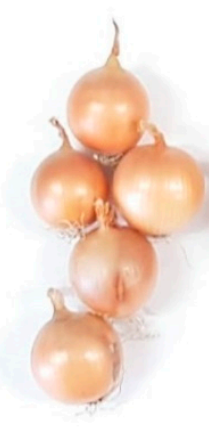

CNT

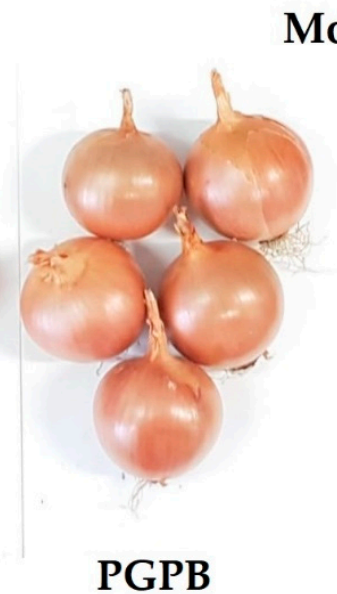

Moondance

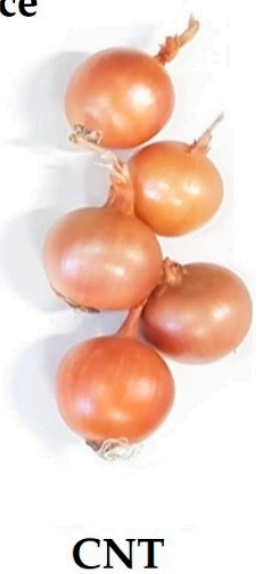

Figure 5. Bulbs harvested from the Control (CNT) and treated (PGPB) experimental units of Meranto and Moondance crops.

Table 2. Soil chemical analysis for Meranto and Moondance experimental conditions.

\begin{tabular}{ccccccc}
\hline \multirow{2}{*}{ Parameter } & \multicolumn{3}{c}{ Moondance } & \multicolumn{3}{c}{ Meranto } \\
\cline { 2 - 6 } & Pre-Sowing & Control & PGPB & Pre-Sowing & Control & PGPB \\
\hline TH & 7.6 & 7.7 & 7.6 & 7.7 & 7.7 & 7.5 \\
Total $\left(\mathrm{g} \mathrm{Kg}^{-1}\right)$ & 2.2 & 2.1 & 2.2 & 2.0 & 1.9 & 2.0 \\
Total Organic Carbon $\left(\mathrm{g} \mathrm{Kg}^{-1}\right)$ & 16.8 & 15.6 & 18.5 & 16.5 & 16.3 & 18.0 \\
Organic Matter $\left(\mathrm{g} \mathrm{Kg}^{-1}\right)$ & 29.0 & 27.0 & 32.0 & 28.4 & 28.0 & 31.0 \\
Electric Conductivity $\left(\mu \mathrm{S} \mathrm{cm}^{-1}\right)$ & 0.45 & 0.42 & 0.32 & 0.40 & 0.40 & 0.33 \\
$\mathrm{Na}^{+}\left(\mathrm{mg} \mathrm{Kg}^{-1}\right)$ & 33.0 & 38.0 & 15.0 & 31.0 & 28.0 & 18.5 \\
$\mathrm{Ca}^{++}\left(\mathrm{mg} \mathrm{Kg}^{-1}\right)$ & 3022.0 & 2895.5 & 3023.2 & 3132.5 & 2998.0 & 3108.5 \\
$\mathrm{Mg}^{++}\left(\mathrm{mg} \mathrm{Kg}^{-1}\right)$ & 148.5 & 130.5 & 153.0 & 145.0 & 123.2 & 126.5 \\
$\mathrm{~K}^{+}\left(\mathrm{mg} \mathrm{Kg}^{-1}\right)$ & 489.0 & 383.0 & 413.5 & 164.5 & 138.0 & 182.2 \\
Available P $\left(\mathrm{mg} \mathrm{P}_{2} \mathrm{O}_{5} \mathrm{Kg}^{-1}\right)$ & 323.0 & 172.0 & 460.5 & 282.0 & 144.2 & 227.0 \\
\hline
\end{tabular}

$16 \mathrm{~S}$ rRNA gene analysis allowed us to obtain the characterization of the soil microbial community of archaea and bacteria. At the ecological level, compared to the Control soil, the microbial community was positively influenced in terms of diversity and richness. The number of individuals and the Shannon-Wiener $\mathrm{H}^{\prime}$ and Chao-1 diversity indexes were higher than those of the Control (Table 3).

Table 3. Ecological indexes calculated from Illumina sequencing results.

\begin{tabular}{|c|c|c|c|c|}
\hline \multicolumn{2}{|c|}{ Index } & \multirow{2}{*}{$\begin{array}{c}\text { Individuals } \\
7431\end{array}$} & \multirow{2}{*}{$\begin{array}{c}\text { Shannon-Wiener } \mathbf{H}^{\prime} \\
6.15\end{array}$} & \multirow{2}{*}{$\begin{array}{c}\text { Chao-1 } \\
628\end{array}$} \\
\hline & Control & & & \\
\hline Moondance & PGPB & 9627 & 6.33 & 753 \\
\hline \multirow[b]{2}{*}{ Meranto } & Control & 4046 & 5.66 & 363 \\
\hline & PGPB & 5209 & 5.79 & 429 \\
\hline
\end{tabular}

The microbial community recorded changes in terms of composition. As shown in Figure 6, the ASVs (amplicon sequence variants) association at the genus level allowed us to establish how the microbial community was changed by bacterial presence. In general, the PGPB treatment recorded increases in the richness of most genera compared to the Control (including the unknown group), with an increase in the Lysobacter genus in both Meranto and Moondance PGPB samples. This indicates a cultivar-dependent community and PGPB-dependent enrichment. The ASVs of all samples were mainly associated with unknown Bacteria (30\% on average) and Chloroflexi and Proteobacteria phyla. 


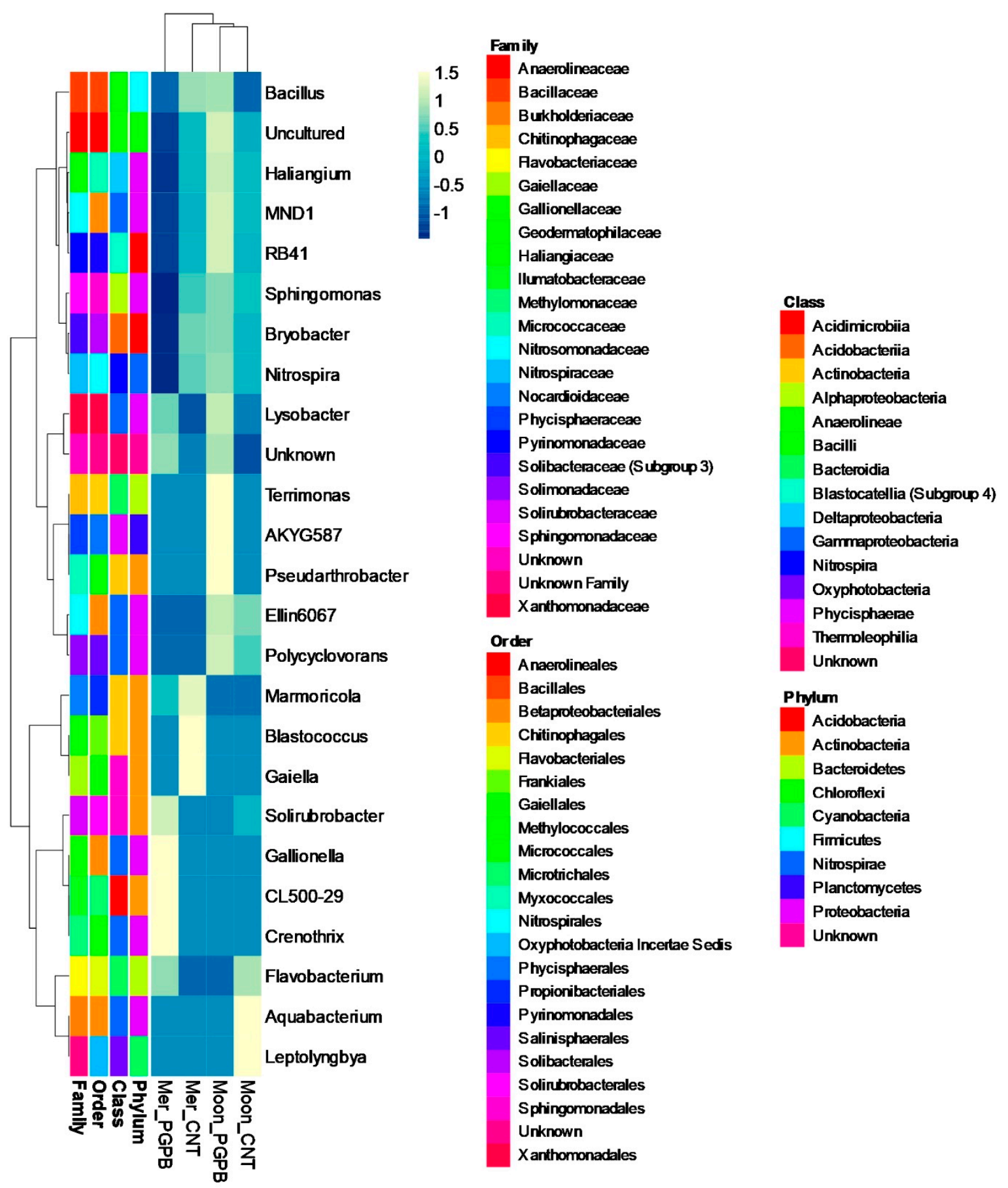

Figure 6. Heat-map and clustering of the soil microbial community composition of the Control (CNT) and treated (PGPB) experimental conditions of Meranto (Mer) and Moondance (Moon) crops. The color changes in the panel show the percentage occupied by the genus inside each sample (color scale at the top). Taxonomy is indicated by the color keys on the right.

\section{Discussion}

The use of biostimulants in agriculture is steadily increasing around the world due to the effectiveness and sustainability of this fertilization approach. The growing use of these innovative products, together with the growing global food demand and the worsening of environmental problems, requires the formulation of new biostimulants. Nevertheless, although plant biostimulants prove to be a valid alternative to synthetic fertilizers, it is necessary to create a valid scientific background that can help the diffusion of these products 
and sustainable agriculture. Among plant biostimulants, microbial formulations have been investigated since the late 1970s for their plant growth-promoting characteristics. In the last decades, different indirect and direct plant-promotion mechanisms have been ascribed to numerous PGPB strains and their application on seeds/plants by several approaches tested [31]. In this study, we selected one of the simplest application methods, seed inoculation, demonstrating the attachment and survival of microorganism for up to 30 days. This approach has already been proven to be valid a strategy for the improvement of various open field cultivations, both in research and in pre-commercial trials [32]. The ability of bacteria to produce these aggregation structures, known as biofilms, is a fundamental characteristic generally attributed to strains belonging to PGPB and is a key element for their association with plants [4]. Seed soaking with inoculants allows for a good long-term survival of microorganisms, transporting them directly to the plant's rhizosphere [32], where they can increase plant growth through numerous mechanisms [33]. Biometric results obtained from onion crops (i.e., height, chlorophylls, and dry matter) and bulbs (i.e., yield, dry weight, total phenolic content, and antioxidant activity) showed that seed bacterial treatment improved plant growth and development. Our results are consistent with many previous studies on different crops which recorded similar inoculation effects on soil fertility status [34,35] and on crops. Among those related to onion crops, seed treatment with inoculation of Azotobacter chroococcum MF135558 and adhesive agents, in the presence of a 75\% dose of NK, improved the growth and yield of plants in a field experiment [36]. Samayoa et al. [37] reported effective isolation and reinoculation of Leifsonia sp., Bacillus megaterium, and Pantoea sp. on onions in combination with a half-dose of chemical fertiliser, recording an improvement in growth during the vegetative stage under pot cultivation. Tinna et al. [38] reported that the integrated use of an Azotobacter sp., Sphingobacterium sp., and Burkholderia sp. consortium as a root dip of seedlings along with mineral fertilizers resulted in improved onion plant growth, bulb yield, and bulb quality parameters. These positive results are usually linked to the production of a certain amount plant growthpromoting (PGP) substances such as indole-3-acetic acid, which promotes the development of root length, volume, and cell division [39] as well as chlorophyll synthesis [40]. $\mathrm{N}_{2}$ fixation is another PGP strategy that improves $\mathrm{N}$ uptake by plants [41] and the synthesis of siderophores, enzymes, hormones, and essential elements [42], resulting in an increase in plant dry matter [43]. The improved uptake of nutrients mediated by bacteria affects not only nitrogen but also other macro- and micronutrients. The chemical analyses conducted on the soil showed how seed inoculation promoted the release of available phosphorus and the increase in total organic carbon and organic matter. The increase in available phosphorus, without changing the soil composition, is related to the ability of bacteria (PSB) to mobilize insoluble forms of phosphorus, converting them into forms accessible to the plant, and has been described for many genera (Rhizobium, Pseudomonas, Azotobacter, and Bacillus) [44]. Microbial inoculation is one of the tools used to modify the characteristics of the soil in productive landscapes. Maintaining good organic carbon levels can be achieved by carbon-sequestering microbial inoculants with the ability to promote carbon sequestration and soil storage [45]. Several PGPB have been shown to have the ability to increase soil carbon levels. However, organic carbon arises from interactions between roots and the rhizospheric microbial community and is influenced by many environmental factors (e.g., nutrient availability, $\mathrm{pH}$, moisture, climatic conditions, atmospheric $\mathrm{CO}_{2}$ ) [46] The presence of bacterial inoculum also promotes positive changes in the richness and composition of the soil microbial community. How PGPB induce this modification has not yet been clarified [47]. However, it must always be taken into account that also soil composition and plant cultivar influence microbial community structure $[48,49]$. The abundance and distribution of microorganisms within a community can be modified by the PGPB application [50]. Therefore, to try to establish how and to what extent PGPB can affect the soil microbial community, a multidisciplinary study with the evaluation of all these variables should be carried out. 


\section{Conclusions}

The present study allowed us to estimate the effects of seed inoculation on productive onion landscapes. The bacterial consortium of the four selected strains Azospirillum brasilense, Burkholderia ambifaria, Gluconacetobacter diazotrophicus, and Herbaspirillum seropedicae was tested in open field experiments on onion. Evaluation of biometrical parameters on plant and bulbs, as well as soil physico-chemical and molecular characterization, revealed that seed treatment improved plant growth and development, crop yield and quality, and the soil fertility status. These results, together with other previously published and unpublished research, confirm the suitability of this consortium as a biostimulating agent in sustainable agriculture. The optimization of large-scale inoculum production procedures as well as the stability of the formulation should be investigated. Furthermore, future studies should be directed towards the creation of scientific evidence on the suitability of this inoculant application on other plant species and the elucidation of the mechanisms of plant-growth improvement and fertility status and changes in the microbial community. Our results suggest that seed inoculation with this consortium could be used in productive onion landscapes as a biostimulating agent in place of chemical fertilizers.

Author Contributions: Conceptualization, M.D.G. and D.M.S.; methodology, C.E.; formal analysis, M.P.; investigation, M.P.; data curation, M.P.; writing—original draft preparation, M.P. and D.M.S.; writing-review and editing, M.D.G.; supervision, M.D.G.; project administration, D.M.S. All authors have read and agreed to the published version of the manuscript.

Funding: This research was funded by "Programma Operativo Regionale (POR-FESR)—Azione 1.1.1 Progetti di Ricerca Industriale e Sviluppo Sperimentale delle Imprese afferenti ai Domini individuati nella RIS3 della Regione Abruzzo-INNOPAQ CUP C43D18000130007".

Acknowledgments: We wish to thank "Azienda Agricola Scipioni" for the provision and for the cultivation of experimental fields and Lorenzo Arrizza for support with the scanning electron microscope analysis.

Conflicts of Interest: The authors declare no conflict of interest. The funders had no role in the design of the study; in the collection, analyses, or interpretation of data; in the writing of the manuscript, or in the decision to publish the results.

\section{References}

1. Rouphael, Y.; Colla, G. Editorial: Biostimulants in Agriculture. Front. Plant Sci. 2020, 11, 40. [CrossRef]

2. du Jardin, P. Plant biostimulants: Definition, concept, main categories and regulation. Sci. Hortic. 2015, 196, 3-14. [CrossRef]

3. Colla, G.; Nardi, S.; Cardarelli, M.; Ertani, A.; Lucini, L.; Canaguier, R.; Rouphael, Y. Protein hydrolysates as biostimulants in horticulture. Sci. Hortic. 2015, 196, 28-38. [CrossRef]

4. Djebaili, R.; Pellegrini, M.; Smati, M.; Del Gallo, M.; Kitouni, M. Actinomycete Strains Isolated from Saline Soils: Plant-GrowthPromoting Traits and Inoculation Effects on Solanum lycopersicum. Sustain. J. Rec. 2020, 12, 4617. [CrossRef]

5. Khoshru, B.; Mitra, D.; Khoshmanzar, E.; Myo, E.M.; Uniyal, N.; Mahakur, B.; Das Mohapatra, P.K.; Panneerselvam, P.; Boutaj, H.; Alizadeh, M.; et al. Current scenario and future prospects of plant growth-promoting rhizobacteria: An economic valuable resource for the agriculture revival under stressful conditions. J. Plant Nutr. 2020, 43, 3062-3092. [CrossRef]

6. Mahmood, A.; Turgay, O.C.; Farooq, M.; Hayat, R. Seed biopriming with plant growth promoting rhizobacteria: A review. FEMS Microbiol. Ecol. 2016, 92, fiw112. [CrossRef]

7. Bashan, Y.; De-Bashan, L.E. How the Plant Growth-Promoting Bacterium Azospirillum Promotes Plant Growth—A Critical Assessment. Adv. Agron. 2010, 108, 77-136. [CrossRef]

8. Raja, P.; Uma, S.; Gopal, H.; Govindarajan, K. Impact of bio inoculants consortium on rice root exudates, biological nitrogen fixation and plant growth. J. Biol. Sci. 2006, 6, 815-823. [CrossRef]

9. Rajasekar, S.; Elango, R. Effect of microbial consortium on plant growth and improvement of alkaloid content in Withania somnifera ( Ashwagandha). Curr. Bot. 2011, 2, 27-30.

10. Cappellari, L.D.R.; Santoro, M.V.; Nievas, F.; Giordano, W.; Banchio, E. Increase of secondary metabolite content in marigold by inoculation with plant growth-promoting rhizobacteria. Appl. Soil Ecol. 2013, 70, 16-22. [CrossRef]

11. Döbereneir, J. The genera Azospirillum and Herbaspirillum. In The Prokaryotes: A Handbook on the Biology of Bacteria: Ecophysiology, Isolation, Identification, Applications; Balows, A., Trüper, H.G., Dworkin, M., Harder, W., Schleifer, K.-H., Eds.; Springer: New York, NY, USA, 1991; pp. 2236-2253. 
12. Moretti, L.G.; Crusciol, C.A.C.; Kuramae, E.E.; Bossolani, J.W.; Moreira, A.; Costa, N.R.; Alves, C.J.; Pascoaloto, I.M.; Rondina, A.B.L.; Hungria, M. Effects of growth-promoting bacteria on soybean root activity, plant development, and yield. Agron. J. 2019, 112, 418-428. [CrossRef]

13. Sarma, B.K.; Yadav, S.K.; Singh, S.; Singh, H.B. Microbial consortium-mediated plant defense against phytopathogens: Readdressing for enhancing efficacy. Soil Biol. Biochem. 2015, 87, 25-33. [CrossRef]

14. Shahzad, S.; Khan, M.Y.; Zahir, Z.A.; Asghar, H.N.; Chaudhry, U.K. Comparative Effectiveness of Different Carriers To Im-prove the Efficacy. Pakistan J. Bot. 2017, 49, 1523-1530.

15. Dwivedi, M. Gluconobacter. In Beneficial Microbes in Agro-Ecology; Amaresan, N., Senthil Kumar, M., Annapurna, K., Kumar, K., Sankaranarayanan, A., Eds.; Academic Press: Cambridge, MA, USA, 2020; pp. 521-544.

16. Monteiro, R.A.; Balsanelli, E.; Wassem, R.; Marin, A.M.; Brusamarello-Santos, L.C.C.; Schmidt, M.A.; Tadra-Sfeir, M.Z.; Pankievicz, V.C.S.; Cruz, L.M.; Chubatsu, L.S.; et al. Herbaspirillum-plant interactions: Microscopical, histological and molecular aspects. Plant Soil 2012, 356, 175-196. [CrossRef]

17. Castanheira, N.; Dourado, A.; Kruz, S.; Alves, P.; Delgado-Rodríguez, A.; Pais, I.P.; Semedo, J.N.; ScottiCampos, P.; Sanchez, C.R.M.; Borges, N.; et al. Plant growth-promoting Burkholderia species isolated from annual ryegrass in Portuguese soils. J. Appl. Microbiol. 2016, 120, 724-739. [CrossRef]

18. Fiore, A.; Laevens, S.; Bevivino, A.; Dalmastri, C.; Tabacchioni, S.; Vandamme, P.; Chiarini, L. Burkholderia cepacia complex: Distribution of genomovars among isolates from the maize rhizosphere in Italy. Environ. Microbiol. 2001, 3, 137-143. [CrossRef]

19. Kloepper, J.W.; Leong, J.; Teintze, M.; Schroth, M.N. Enhanced plant growth by siderophores produced by plant growth-promoting rhizobacteria. Nat. Cell Biol. 1980, 286, 885-886. [CrossRef]

20. Thomloudi, E.-E.; Tsalgatidou, P.; Douka, D.; Spantidos, T.-N.; Dimou, M.; Venieraki, A.; Katinakis, P. Multistrain versus single-strain plant growth promoting microbial inoculants-The compatibility issue. Hell. Plant Prot. J. 2019, 12, 61-77. [CrossRef]

21. Botta, A.L.; Santacecilia, A.; Ercole, C.; Cacchio, P.; Del Gallo, M. In vitro and in vivo inoculation of four endophytic bacteria on Lycopersicon esculentum. New Biotechnol. 2013, 30, 666-674. [CrossRef]

22. Pagnani, G.; Pellegrini, M.; Galieni, A.; D’Egidio, S.; Matteucci, F.; Ricci, A.; Stagnari, F.; Sergi, M.; Sterzo, C.L.; Pisante, M.; et al. Plant growth-promoting rhizobacteria (PGPR) in Cannabis sativa 'Finola' cultivation: An alternative fertilization strategy to improve plant growth and quality characteristics. Ind. Crop. Prod. 2018, 123, 75-83. [CrossRef]

23. Pace, L.; Pacioni, G.; Spanò, L. In vitro propagation of Artemisia petrosa ssp. eriantha: Potential for the preservation of an endangered species. Plant Biosyst. 2004, 138, 291-294. [CrossRef]

24. Pagnani, G.; Galieni, A.; Stagnari, F.; Pellegrini, M.; Del Gallo, M.; Pisante, M. Open field inoculation with PGPR as a strategy to manage fertilization of ancient Triticum genotypes. Biol. Fertil. Soils 2020, 56, 111-124. [CrossRef]

25. Raikhel, N.V. Plant Physiology's Best Paper Award 2002. Plant Physiol. 2003, 132, 3. [CrossRef]

26. Singleton, V.L.; Rossi, J.A. Colorimetry of Total Phenolics with Phosphomolybdic-Phosphotungstic Acid Reagents. Am. J. Enol. Vitic. 1965, 16, 144-158.

27. Brand-Williams, W.; Cuvelier, M.; Berset, C. Use of a free radical method to evaluate antioxidant activity. LWT 1995, 28, 25-30. [CrossRef]

28. Vaccarelli, I.; Matteucci, F.; Pellegrini, M.; Bellatreccia, F.; Del Gallo, M. Exploring Microbial Biosignatures in Mn-Deposits of Deep Biosphere: A Preliminary Cross-Disciplinary Approach to Investigate Geomicrobiological Interactions in a Cave in Central Italy. Front. Earth Sci. 2021, 9, 590257. [CrossRef]

29. Bolyen, E.; Rideout, J.R.; Dillon, M.R.; Bokulich, N.A.; Abnet, C.C.; Al-Ghalith, G.A.; Alexander, H.; Alm, E.J.; Arumugam, M.; Asnicar, F.; et al. Reproducible, interactive, scalable and extensible microbiome data science using QIIME 2. Nat. Biotechnol. 2019, 37, 852-857. [CrossRef]

30. Oksanen, J.; Blanchet, F.; Friendly, M.; Kindt, R.; Legendre, P.; McGlinn, D.; Minchin, P.; O’Hara, B.; Simpson, G.; Solymos, P.; et al The Vegan Package. Available online: https://cran.r-project.org/web/packages/vegan/vegan.pdf (accessed on 28 July 2020).

31. Bashan, Y.; De-Bashan, L.E.; Prabhu, S.R.; Hernandez, J.-P. Advances in plant growth-promoting bacterial inoculant technology: Formulations and practical perspectives (1998-2013). Plant Soil 2014, 378, 1-33. [CrossRef]

32. O'Callaghan, M. Microbial inoculation of seed for improved crop performance: Issues and opportunities. Appl. Microbiol. Biotechnol. 2016, 100, 5729-5746. [CrossRef]

33. Babalola, O.O. Beneficial bacteria of agricultural importance. Biotechnol. Lett. 2010, 32, 1559-1570. [CrossRef] [PubMed]

34. Orhan, E.; Esitken, A.; Ercisli, S.; Turan, M.; Sahin, F. Effects of plant growth promoting rhizobacteria (PGPR) on yield, growth and nutrient contents in organically growing raspberry. Sci. Hortic. 2006, 111, 38-43. [CrossRef]

35. Ullah, A.; Bano, A. Role of PGPR in the reclamation and revegetation of saline land. Pak. J. Bot. 2019, 51, 27-35. [CrossRef]

36. Afify, A.; Hauka, F.; ElSawah, A. Plant Growth-Promoting Rhizobacteria enhance Onion (Allium cepa L.) productivity and minimize requisite chemical fertilization. Environ. Biodivers. Soil Secur. 2019. [CrossRef]

37. Samayoa, B.E.; Shen, F.-T.; Lai, W.-A.; Chen, W.-C. Screening and Assessment of Potential Plant Growth-promoting Bacteria Associated with Allium cepa Linn. Microbes Environ. 2020, 35. [CrossRef]

38. Tinna, D.; Garg, N.; Sharma, S.; Pandove, G.; Chawla, N. Utilization of plant growth promoting rhizobacteria as root dipping of seedlings for improving bulb yield and curtailing mineral fertilizer use in onion under field conditions. Sci. Hortic. 2020, 270, 109432. [CrossRef] 
39. Wahyudi, A.T.; Priyanto, J.A.; Afrista, R.; Kurniati, D.; Astuti, R.I.; Akhdiya, A. Plant Growth Promoting Activity of Actinomycetes Isolated from Soybean Rhizosphere. Online J. Biol. Sci. 2019, 19, 1-8. [CrossRef]

40. Czerpak, R.; Dobrzyń, P.; Krotke, A.; Kicińska, E. The Effect of auxins and salicylic acid on chlorophyll and carotenoid contents in Wolffia arrhiza (L.) Wimm. (Lemnaceae) growing on media of various trophicities. Polish J. Environ. Stud. 2002, 11, $231-235$.

41. Boddey, R.M.; Urquiaga, S.; Alves, B.J.; Reis, V. Endophytic nitrogen fixation in sugarcane: Present knowledge and future applications. Plant Soil 2003, 252, 139-149. [CrossRef]

42. Badawi, F.; Biomy, A.; Desoky, A. Peanut plant growth and yield as influenced by co-inoculation with Bradyrhizobium and some rhizo-microorganisms under sandy loam soil conditions. Ann. Agric. Sci. 2011, 56, 17-25. [CrossRef]

43. Venieraki, A.; Dimou, M.; Pergalis, P.; Kefalogianni, I.; Chatzipavlidis, I.; Katinakis, P. The Genetic Diversity of Culturable Nitrogen-Fixing Bacteria in the Rhizosphere of Wheat. Microb. Ecol. 2010, 61, 277-285. [CrossRef]

44. Kalayu, G. Phosphate Solubilizing Microorganisms: Promising Approach as Biofertilizers. Int. J. Agron. 2019, 2019, 1-7. [CrossRef]

45. Ahmed, A.A.Q.; Odelade, K.A.; Babalola, O.O. Microbial Inoculants for Improving Carbon Sequestration in Agroecosystems to Mitigate Climate Change. In Handbook of Climate Change Resilience; Springer International Publishing: Cham, Switzerland, 2019; pp. $1-21$.

46. Song, W.; Tong, X.; Liu, Y.; Li, W. Microbial Community, Newly Sequestered Soil Organic Carbon, and $\delta 15 \mathrm{~N}$ Variations Driven by Tree Roots. Front. Microbiol. 2020, 11, 314. [CrossRef]

47. Ren, H.; Huang, B.; Fernández-García, V.; Miesel, J.; Yan, L.; Lv, C. Biochar and Rhizobacteria Amendments Improve Several Soil Properties and Bacterial Diversity. Microorganisms 2020, 8, 502. [CrossRef] [PubMed]

48. Jiang, Y.; Li, S.; Li, R.; Zhang, J.; Liu, Y.; Lv, L.; Zhu, H.; Wu, W.; Li, W. Plant cultivars imprint the rhizosphere bacterial community composition and association networks. Soil Biol. Biochem. 2017, 109, 145-155. [CrossRef]

49. Inceoğlu, Ö.; Salles, J.F.; Van Elsas, J.D. Soil and Cultivar Type Shape the Bacterial Community in the Potato Rhizosphere. Microb. Ecol. 2012, 63, 460-470. [CrossRef] [PubMed]

50. Hou, J.; Liu, W.; Wang, B.; Wang, Q.; Luo, Y.; Franks, A.E. PGPR enhanced phytoremediation of petroleum contaminated soil and rhizosphere microbial community response. Chemosphere 2015, 138, 592-598. [CrossRef] [PubMed] 